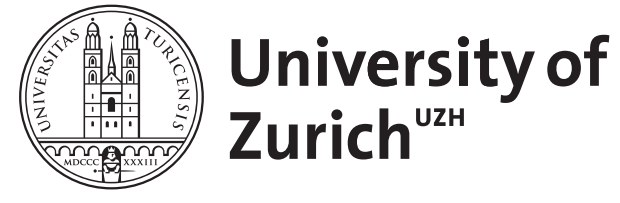
Archive

University of Zurich

University Library

Strickhofstrasse 39

CH-8057 Zurich

www.zora.uzh.ch

Year: 2017

\title{
Some thoughts on the utopian film
}

Spiegel, Simon

DOI: https://doi.org/10.3828/sfftv.2017.3

Posted at the Zurich Open Repository and Archive, University of Zurich

ZORA URL: https://doi.org/10.5167/uzh-142262

Journal Article

Published Version

Originally published at:

Spiegel, Simon (2017). Some thoughts on the utopian film. Science Fiction Film and Television, 10(1):5379.

DOI: https://doi.org/10.3828/sfftv.2017.3 


\title{
Some thoughts on the utopian film1
}

\author{
Simon Spiegel
}

In film, the positive utopia - the eutopia - is basically non-existent. There is a wide agreement among scholars that a typical eutopia lacks some very basic elements of a typical narrative film: it neither features a conflict that drives the plot forward nor real characters with individual traits - both of which are required by feature films in the classical Hollywood tradition. This article argues that there are areas beyond Hollywood mainstream movies that are much better suited for filmic utopias. After all, the literary utopia is characterised by its hybrid nature; it is a blend between narrative and philosophic dialogue. In the classic utopia, the fictional story only serves as a frame for the detailed description of the utopian state. The primary goal of this draft is not an exact implementation, but rather a reminder that alternatives can be conceived. Utopias in this sense are much more tightly bound to a specific historical reality; therefore, non-fiction films are much better suited for utopias. The article gives a theoretical sketch of how utopias and documentaries fit together and analyses Peter Joseph's Zeitgeist: Addendum as an exemplary utopian non-fiction film.

Keywords: utopia, film, non-fiction film, propaganda, utopian film

As a literary genre, the utopian novel has a long and distinguished tradition. Beginning with Thomas More's founding text Utopia in 1516, there has been a steady stream of outlines of a better state. In film, however, the positive utopia - the eutopia - seems to be non-existent. There is wide agreement among scholars that a classic positive utopia lacks some of the basic elements required for a narrative film. In this article, I want to offer a different perspective and sketch out a research programme on utopian film. I believe that utopian films in the Morean tradition do exist, but that we have been looking in the wrong place. Fiction films are indeed unsuited for positive utopias, but as soon as we turn to non-fiction films, we find many examples that largely fit the paradigm set up by More. I will first discuss the concept of utopia and then deal with the relationship between utopia and film. After analysing some examples of utopian films, I will finish with some general thoughts on utopias and non-fiction film.

1. This article is based on two German publications of mine ('Authentische', 'Auf der Suche').

Science Fiction Film and Television 10.1 (2017), 53-79

(c) Liverpool University Press

https://doi.org/10.3828/sfftv.2017.3 


\section{Simon Spiegel}

\section{Generic problems}

One of the main problems of utopian research is the lack of a unified nomenclature: there is no consensus regarding what 'utopia' actually means. Depending on the context, the neologism coined by Thomas More can mean quite different things. In colloquial speech, 'utopian' often has pejorative connotations. We use it to denote illusory or crazy ideas, pies in the sky that no one should take seriously. As soon as we turn to academic discourse, we encounter different traditions of research, which, despite some overlaps, can differ quite substantially; there is even disagreement on the nature of the object under discussion. Is utopia a genre, a political or sociological concept, a philosophical stance or an anthropological constant?

In an often quoted paper, Lyman Tower Sargent distinguishes between 'Utopian literature [...]; communitarianism; and Utopian social theory' ('Three Faces' 4), which are all expressions of 'social dreaming' (3); on the other hand, political scientist Thomas Schölderle, who primarily looks at Germanspeaking social sciences, differentiates between three academic traditions: literary studies, theories of totalitarianism and social psychology.

In both cases, looking at utopias from the perspective of (literary) genre theory is only one of several possibilities - but it is the chosen approach in this article. When I talk about utopia, I mean the literary - or, in my case, filmic

- genre as it was 'invented' by More. In my understanding of genre, I follow film scholar Rick Altman, who conceives of genres as groups of films that share certain semantic and syntactic elements. By semantic, Altman means the 'building blocks' of a genre: typical characters, props and locations, but also stylistic features such as a typical way of framing or the pace of editing. The syntax, on the other hand, describes the way the semantic elements are connected with one another; this mainly refers to the structure of the plot and its dramatic rendition. Additionally, a third level, the question of how genres are used, comes into play. Since genres are not Platonic entities that remain stable over time, but are instead objects of discourse that can vary considerably depending on the specific context, the pragmatic level, as Altman calls it, is of great importance. Ultimately, genres can never be pinned down with some fixed, abstract rule, but can only be described in their historical evolution (see also Neale Genre).

Concerning the concept of utopia, I follow Schölderle, who develops a useful framework for describing classic utopias in his 2011 study Utopia und Utopie. Starting with More's Utopia as the prototype, he undertakes a journey through the history of utopian literature and its research to refine his model. Although 
Schölderle is a political scientist, his study relies heavily on work by literary scholars such as Hans Ulrich Seeber, Peter Kuon and Wilhelm Voßkamp, and has in turn proved useful in that field.2

Since Utopia lies at the heart of Schölderle's model, its interpretation is crucial for the understanding of the whole genre. One of the main questions one must face when dealing with More's text is 'how far More intends us to admire the portrait of Utopian society' (Quentin Skinner 141). Is the commonwealth described really the one its author dreamt of, or should the text be understood in a different way? Although it has often been read as a more or less straightforward political programme, upon closer inspection More's book turns out to be riddled with contradictions and ironic twists that undermine an easy, unambiguous interpretation. For example, the (enthusiastic) account of a society on the legendary island of Utopia is framed through a character called Raphael Hythloday, whose last name can be translated either as 'enemy' or as 'dispenser of nonsense'. The value of his report changes dramatically depending on how we understand his name. In addition, the actual narrator of the story that frames Hythloday's report is a character named Thomas Morus, who turns out to be rather sceptical about the feasibility of a utopian society. This elaborate framing already makes it difficult to judge properly the book's actual contents.

Furthermore, some of Utopia's institutions and regulations turn out to be somewhat questionable. For example, although Hythloday emphasises how strongly the Utopians detest war, he gives many reasons for them to go to battle, among them the lack of space for their own population and the obvious superiority of their political system. What starts as a declaration of peacefulness ends as a justification of quasi-imperialist politics.

Utopia is therefore a highly ambiguous, sometimes openly contradictory book. Referring to Mikhail Bakhtin and Boris Uspensky, Artur Blaim calls it a heteroglossia or polyphonic text (33-8) that is designed to leave crucial points undetermined, 3 and, as Schölderle argues, it was not meant as a political programme, but rather as a critique of the political and social situation in

2 Schölderle does not claim that his approach is fundamentally new. In literary studies, it is quite common to regard More's text as a model for the whole genre. In political science, Richard Saage has been a big supporter of this stance ('Plädoyer', 'Zum analytischen Potenzial'). The main advantage of Schölderle's model is that it takes the contradictions of More's text seriously (see below).

3. On a rhetorical level, this is visible in the common use of the device of litotes, the double negation. As Elizabeth McCutcheon has shown, this figure of speech is characteristic of the text: 'The figure becomes, ultimately, a paradigm of the structure and method of the book as a whole, echoing, often in the briefest of syntactical units, the larger, paradoxical and double vision which will discover the best state of the commonwealth in an island called Noplace' (109). 


\section{Simon Spiegel}

the England of More's time. This is made explicit in the first book, where some of the urgent contemporary social problems are openly addressed. The first part, with its direct criticism, and the second book, with its description of an alternative society, function in tandem: together they make clear that the current deficient situation is not a given; things could be different. What More is interested in is not 'to turn fiction into reality, but rather, through the description of Utopia, look at reality with a sharpened eye' (Schölderle 91).4

This conception dominates utopian studies today. Depending on author and focus, utopias are understood as a 'serious intellectual game' (Kuon 133), as 'carnival/funfair mirror in reverse' (Sargent, 'In Defense' 12), as 'fundamentally a satiric mode' (Roberts viii), as 'thought experiment' (Werder 16) or as 'the Imaginary Reconstitution of Society' (Levitas xi). What all these approaches have in common is that utopias are not so much about the depicted utopian state, but rather a reflection of the deficits of the present. They have a 'normative ... intention' (Schölderle 479) insofar as they demonstrate that alternatives can (and probably should) be conceived, but they are not, at least not primarily, a blueprint for a better society. As Paul Ricoeur puts it: "From this "no place" an exterior glance is cast on our reality, which suddenly looks strange, nothing more being taken for granted' (16).

At the end of his study, Schölderle presents a table that lists constitutive, typical and contingent elements of literary utopias. Not all of them are important for my purpose, but they can be easily mapped onto Altman's triadic model. Besides their critical tendency and the fact that most utopias are not actually meant to be realised, questions of form and content are my main concern.

Utopias always tell of a place which does not (yet) exist and they often (though not always) do this in the form of a narrative.5 Recurring elements of utopias are their isolated location, the static quality of their design (which often goes hand in hand with the abolition of the political process) and a system of common property. Also prevalent is uniformity, which is visible in the cities' layout as well as in the lack of well-rounded characters. A utopian society depends on a utopian individual who knows no envy, greed or hate and who ultimately lacks original thought; or, as Stephen Greenblatt puts it in his discussion of Utopia: 'Utopian institutions are cunningly designed to reduce the scope of the ego' (39).6 To produce such utopian individuals, education is of

4. Unless stated otherwise, translations from German are my own.

5. Schölderle mentions Gerrard Winstanley's The Law of Freedom (1652) as an example that contains all of the typical elements but that comes in form of a tractate rather than a story (210-8).

6. Most of these descriptions only apply to archistic utopias. In contrast to 'a strand of utopianism 


\begin{tabular}{|c|c|c|c|c|}
\hline $\begin{array}{l}\text { Criterion of } \\
\text { distinction }\end{array}$ & Form & Content & Function & Intention \\
\hline Mandatory & - contrafactual fiction & $\begin{array}{l}\text { - universal socio- } \\
\text { political counter- } \\
\text { image } \\
\text { - ideality } \\
\text { - rationality }\end{array}$ & $\begin{array}{l}\text { - critical description of } \\
\text { the status quo } \\
\text { - putting reality into } \\
\text { perspective } \\
\text { - thought experiment } \\
\text { - horizons of } \\
\text { possibilities }\end{array}$ & $\begin{array}{l}\text { - social criticism } \\
\text { - normative tendency } \\
\text { (intention to improve) }\end{array}$ \\
\hline $\begin{array}{l}\text { Typical } \\
\text { e.g. }\end{array}$ & $\begin{array}{l}- \text { literary fiction } \\
\text { - narrative frame } \\
\text { - includes a variety of } \\
\text { forms }\end{array}$ & $\begin{array}{l}\text { - isolation } \\
\text { - static design } \\
\text { - collectivism } \\
\text { - homogeneity }\end{array}$ & $\begin{array}{l}\text { - social and technical } \\
\text { innovations } \\
\text { - instruction and } \\
\text { education } \\
\text { - capacity to warn/ } \\
\text { detect early on }\end{array}$ & $\begin{array}{l}\text { - not meant to be } \\
\text { realised } \\
\text { - oriented towards } \\
\text { discussion }\end{array}$ \\
\hline $\begin{array}{l}\text { Contingent } \\
\text { e.g. }\end{array}$ & $\begin{array}{l}\text { - literary form (satire, } \\
\text { dialogue, travel } \\
\text { narrative, novel, } \\
\text { exchange of letters, } \\
\text { diary) } \\
\text { - philosophical treatise } \\
\text { - idealised draft of } \\
\text { constitutional }\end{array}$ & $\begin{array}{l}\cdot \text { model of } \\
\text { transformation }\end{array}$ & - entertainment & $\begin{array}{l}\text { - will to put draft into } \\
\text { effect } \\
\text { - philosophy of history/ } \\
\text { social prognostics/ } \\
\text { - blueprint for political } \\
\text { action }\end{array}$ \\
\hline $\begin{array}{l}\text { Method of } \\
\text { interpretation }\end{array}$ & \multicolumn{3}{|c|}{ Text-immanent approach } & $\begin{array}{l}\text { Hermeneutic/ } \\
\text { biographic }\end{array}$ \\
\hline
\end{tabular}

Schölderle's table (480, my translation).

great importance. Utopian citizens need to be educated and sensible in order for them to understand that their way of living is the most reasonable one.

Partly thanks to the success of young adult dystopias such as the Hunger Games franchise, the term 'dystopia' has entered common language; in academic discourse, the distinction between positive utopias and negative dystopias is also well established.7 However, those two forms should not be regarded as clearly separate units, but rather as two opposing poles on a spectrum. Since the basic function of the utopian text is to serve as an alternative to reality, the form is linked closely to satire. Starting with Utopia (whose author was a great admirer of classical satire), many utopian novels are by no means completely positive ideal images, often featuring satirical and/or dystopian elements. On the other hand, the typical dystopian novel (which is largely an invention of the twentieth century), is completely negative (see Layh; Zeissler).

that believes in strong governmental control to achieve the common good', 'the anarchistic utopia is ruled by an Arcadian primitivism that determines the constructed environment, social relations and organization of private/domestic relations' (Pohl 57).

7. Some scholars do distinguish between dystopias that present negative societies and anti-utopias that specifically target utopian approaches. For a detailed discussion of different varieties, see Balasopoulos. 


\section{Simon Spiegel}

As a literary genre, utopia has proved to be amazingly robust and long-lived. While it has undergone massive transformations, especially since the early twentieth century, even the dystopias and the critical utopias of the 1960s and 1970s (see Moylan Demand) that subject the classic model to harsh criticism ultimately depend on it.

\section{In search of utopian film}

There are quite a few publications on film - especially German ones - that contain the attribute 'utopian' in their title, but most of them deal with sf. In German (scientific or technological) utopia and sf are sometimes understood as synonymous, and some authors even claim that sf is the direct successor to the utopian tradition. Nevertheless, although the two genres clearly are closely related, they are by no means identical. Utopias can exist without a novum and they are not necessarily technologically advanced, while sf is often not interested in a detailed description of its society.

Although sf must not necessarily take place in the future, many stories do make this temporal shift, since it simplifies the justification of the novum. In contrast, utopias, for several centuries, have been exclusively utopias of space, located on remote islands. The concept of (technological) progress is unknown to the early utopias, hence their static quality. Beginning only in the late eighteenth century, a process kicks in that Reinhart Koselleck calls the 'temporalisation of utopia' ('Verzeitlichung der Utopie'). The industrial revolution changed the utopian genre profoundly; subsequently, more and more utopias moved into the future and sf nova become the norm. Since the nineteenth century, utopias have therefore mostly existed in the sf mode, 8 though exceptions are still possible. 9

Few authors truly deal with utopias in film and most conclude that a movie that functions analogously to a classic literary utopia is simply not possible. The reasons seem obvious: if a utopia features a narrative, it is normally just a

8. I prefer to speak of $\mathrm{sf}$ as a mode since it describes a certain type of fictional world and cannot be properly restricted to a set of semantic and syntactic elements. Certain genres such as the space opera or the time travel story are firmly rooted in the sf mode; other genres - such as the utopian can easily exist in other modes. For my understanding of sf, see 'Things' and Konstitution.

9. One prominent example of a non-sf utopia of the late nineteenth century is William Morris's News from Nowhere (1890). Although Morris's alternative England is set in the future and does feature some technical advancements such as an electrical boat, these nova are not really important, as they do not shape the fictional world. In many ways, the world of News from Nowhere is a medieval one where artisanship and manual labour are emphasised. 
pretext for the description of 'a non-existent society ... in considerable detail' (Sargent 'Three Faces' 9). Utopian novels lack both the proper plot and the dramatic arc that are essential for fiction films; additionally, their characters are usually bland, without many distinguishing traits. Overall, this is far from a typical Hollywood movie, in which a clearly defined protagonist tries to reach a specified goal against all odds. In contrast, dystopias, which usually feature a rebellious hero, fit the paradigm of a feature film perfectly. It is no surprise that the revolt of a nonconformist protagonist against a future totalitarian regime has been one of the staples of American sf films, from Star Wars (Lucas US 1977) to The Matrix (Wachowskis US 1999) and beyond.10

In 1993, Peter Fitting proposed looking beyond regular feature films in a survey article on utopian film. His appeal provoked little or no reaction. Since then, several studies on utopian film have been published (e.g., Tietgen; Zirnstein; Müller; Endter; Stoppe), all of which follow the argument I have just laid out: they all start with the classic utopia as it was established by More and, after discussing the concept, they all come to the conclusion that a utopian film is - for the reasons just mentioned - an impossible thing. Therefore, they all turn to dystopias and once again analyse the usual suspects; for example, Fahrenheit 451 (Truffaut UK 1966), A Clockwork Orange (Kubrick UK 1971) and Logan's Run (Anderson US 1976).11 Chloé Zirnstein at least identifies Peter Weir's Witness (US 1985) as a rare example of a utopian film, but she also does not leave the safe confines of mainstream cinema. Not even her own remark that documentary films are probably better suited for utopias than fiction films leads her to look for actual examples.

There certainly are films with a utopian edge, like Things to Come (Menzies UK 1936), Born in Flames (Borden US 1983) or - more recently - Tomorrowland.12 Some of them even deal explicitly with the subject of utopianism; however, even those rare examples are still very far from a typical written utopia and none even comes close to the type described by Schölderle. This is, of course, not really surprising; after all, the classic utopia was already a diminishing form by the end of the nineteenth century, when cinema was invented, so there

10. This is even true for Tomorrowland (Bird US/Spain 2015), a movie that, despite its complete suppression of any political thought, shows some utopian traits. Not only is the main character Casey (Britt Robertson) opposed to the negative attitude of her surroundings, but together with Frank (George Clooney), she has to free Tomorrowland from the dictatorial rule of Nix (Hugh Laurie).

11. Stoppe's study Unterwegs zu neuen Welten is an exception here. He focuses on the Star Trek franchise, which in his eyes qualifies as a proper positive utopia. Unfortunately, his line of argument is not very convincing (see my review in Journal for the Fantastic in the Arts).

12. For a discussion of more examples, see Spiegel 'Bilder'. 
certainly are valid reasons why utopia as a genre does not hold the same status as the western or the musical. However, this does not mean that a utopian film is not feasible per se.

The basic mistake most researchers have made is to concentrate on fiction films in the first place. This is a dead end, because utopias are not fiction proper. Although we often talk about 'utopian novels', classic utopias are not novels in the common sense, but hybrids. A literary utopia is a 'rational sociopolitical construction, which acquires a quasi-real look by the means of specific literary devices' (Seeber 12). Its intention is to deliver a critical diagnosis of its time, 'to improve the present' (Schölderle 48), meaning that utopias are, by definition, much more closely linked to a specific social and historical moment than regular novels.13 Utopias are literary bastards 'whose potential lies in the conflict between reality and fiction' (Schölderle 464).

If we take this characterisation as a hybrid seriously, it should become evident why we are unable to find fiction films that fit the Morean paradigm. At the same time, a whole new area for potential research opens up. The focus now moves to forms beyond fiction films, to films that - analogous to literary utopias - mix fictional and non-fictional elements, but are not - or at least not primarily - about telling a story. 14 That means we have to look at films that mix real and fictitious elements and whose main intention is to comment on and criticise the present.

Before giving examples of such films and analysing one in more detail, a qualification is in order. If we follow Altman's approach, we have to be aware of the fact that it is, strictly speaking, impossible to 'discover' a new genre. Genres are objects of discourse that are defined by their users, not rare beasts that exist out there in the wild, waiting to be discovered by a daring scholar. I therefore do not claim that the utopian film has always existed as a distinct genre; rather, I believe that it should prove productive to regard films as utopian that share similarities with literary utopias on a semantic and syntactic level. In this respect, the genre of utopia primarily serves as a heuristic device.

13. This also makes them 'excellent indicators of the time that produced them' (Voßkamp 15).

14. I do not want to give the impression that nonfiction films are non-narrative per se. Documentaries and propaganda films do tell a story, and they follow dramatic principles. Still, they tell factual stories (more on this later). 


\section{Non-fictional utopias}

The following examples should primarily give an idea of the many forms in which utopian films can appear. It is not my intention to be in any way exhaustive, but rather to very roughly stake out the territory for possible further research.

One obvious area is propaganda films. Peter Fitting mentions Leni Riefenstahl's Triumph of the Will (Triumph des Willens; Germany 1935) but states that 'this category might also include more straightforward films, which seek to portray a particular society in glowing positive terms' (6). Among these 'more straightforward films' are Zionist propaganda films such as Land of Promise (L'Chayim Hadashim; Leman Palestine 1935).15 This 57-minute film - the first sound film produced in Palestine - is in many ways a typical product of its time (see Tryster). Accompanied by an authoritarian off-screen narrator, it shows stereotypical images of marching men, off to work the barren desert ground. Land of Promise matches the major points in Schölderle's model: starting from the gloomy present - Jews are persecuted everywhere - it paints an idealised image of an orderly commonwealth. We see how members of a kibbutz work and eat together, and how they enjoy music. The Arab population are portrayed with a kind of condescending benevolence. They represent older times, and their primitive, almost medieval houses and agricultural equipment are contrasted with the modern machines and the high tech laboratories of the Zionists. While we learn little about the political and social organisation of the eponymous 'land of promise', Leman's film does certainly present a 'good place' with a 'normative intention' (Schölderle 479), that is, a good place that at the time of its production did not (yet) exist.

Of quite a different nature are films which were produced in the context of world fairs, for example, To New Horizons (unknown US 1940) and Out of this World (unknown USA 1964).16 Both films were commissioned by General Motors as part of its engagement in the World Fairs of 1939 and 1965 in New York City.17 To New Horizons is based on General Motor's extremely popular Futurama exhibit, which presented a model of the world 20 years hence. The main visual motif of the film is the road leading into the future. This fits nicely with the model's main attraction, an automated highway system, which is shown extensively in the 23-minute film.

\footnotetext{
15. The film is available on YouTube:https://www.youtube.com/watch?v=QDoD6W2z01s.

16. Fitting also mentions World Fairs as a possible place to look for utopian films.

17. Both films are available online: To New Horizons (https://www.youtube.com/watch?v= tAz4R6F0aaY); Out of This World (https://www.youtube.com/watch?v=b0l_DBzwQEs).
} 

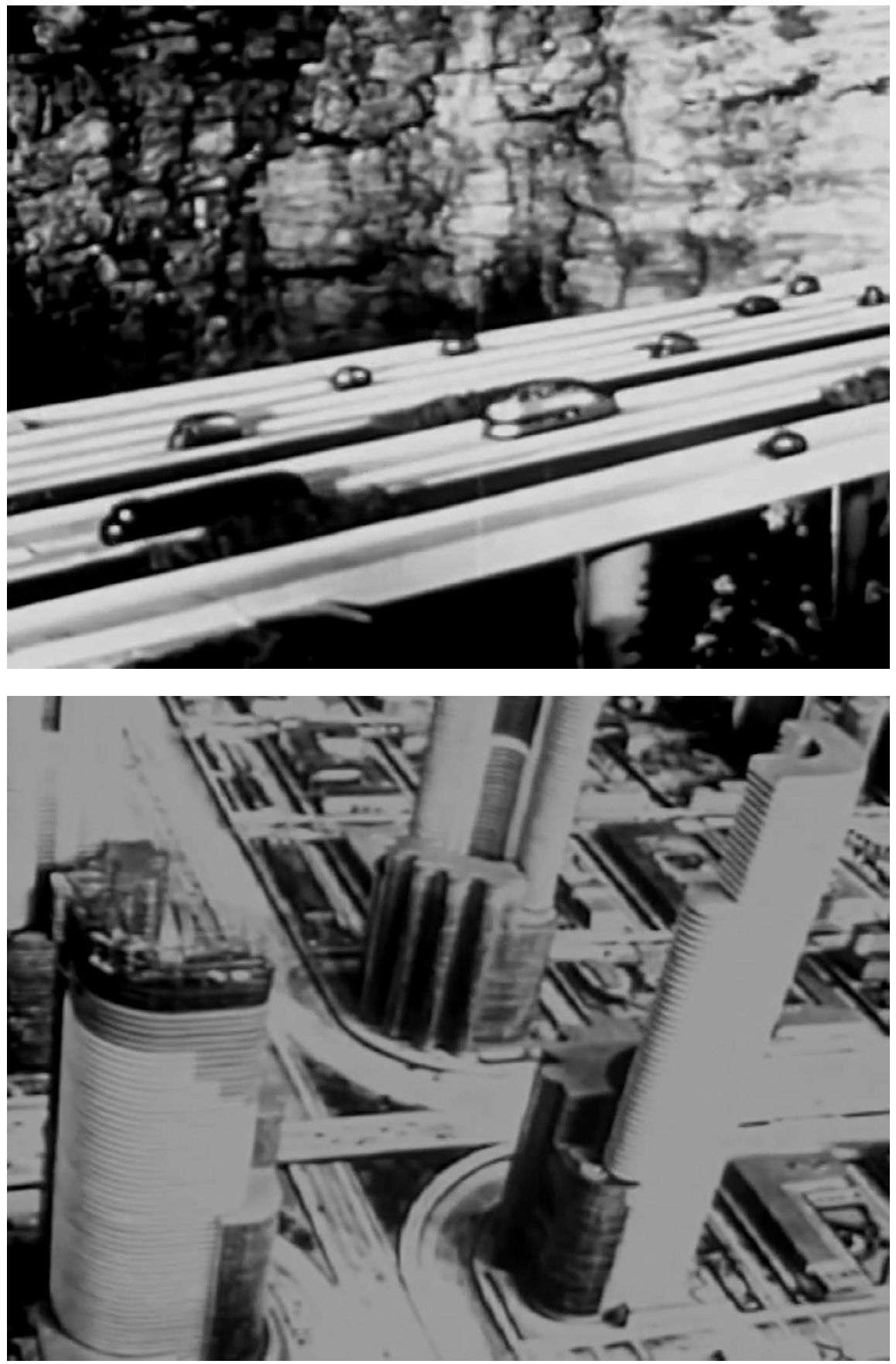

To New Horizons. https://www.youtube.com/watch?v=tAz4R6F0aaY. 
Produced a quarter of a century later, Out of this World consists of two main parts. In the first section, the film envisions the future colonisation of Antarctica and the ocean floor, as well as the exploitation of tropical forests and mountains. After briefly touching on the metropolis of the future, the longer second part somewhat surprisingly focuses on the 'kitchen of the future'. All kinds of appliances that elate the housewife - like 'an oven that can cook a roast in minutes' - are shown.

Both General Motors films are much closer to traditional PR films than Land of Promise; they also, unsurprisingly, do not touch on political issues. However, unlike Leman's film, whose emphasis lies on the present or the immediate future - the promised land is being built right now - their main concern is the world several decades from now. Both films also lack any critical edge; we hear nothing about how bad things currently are. Quite the contrary; things seem to be quite good already, and therefore the future these films envision is in many ways simply an extension of the present. This becomes especially evident in Out of this World; while the kitchen of the future is much more advanced, cooking and cleaning are naturally still the duty of women.

A film that is in some ways related to General Motor's World Fair productions but which descends more directly from the utopian tradition is The EPCOT Film (unknown US 1966) - sometimes also called The Florida Project - which Walt Disney produced only two months before his death. Although many of Disney's views were stoutly conservative, he was also a utopian of sorts, and his amusements parks especially can be seen as attempts to build a perfect city. For Disney World, which was going to be built in Florida, the studio mogul was even more ambitious. It was not only to include traditional theme parks and an 'airport of the future', but also an Experimental Prototype City Of Tomorrow: EPCOT, 'the heart of everything we'll be doing in Disney World', was meant to be a test bed for city planning, where 20,000 people would actually work and live. EPCOT's declared mission was 'finding solutions to the problems of our cities' and, while these 'problems' are never spelled out, the film goes to great lengths to show how they would be solved. EPCOT is divided into discrete areas: a district of commerce in the centre, community buildings and schools and recreational complexes around it, and residential neighbourhoods in the outer circle.18

The EPCOT Film begins with images of Disneyland and quotations that praise the place's superb organisation; special emphasis is put on the various

18. On EPCOT, see Gennawey, and Knight 102-38. The film is available online: https://youtu.be/ UEm-09B0px8. 


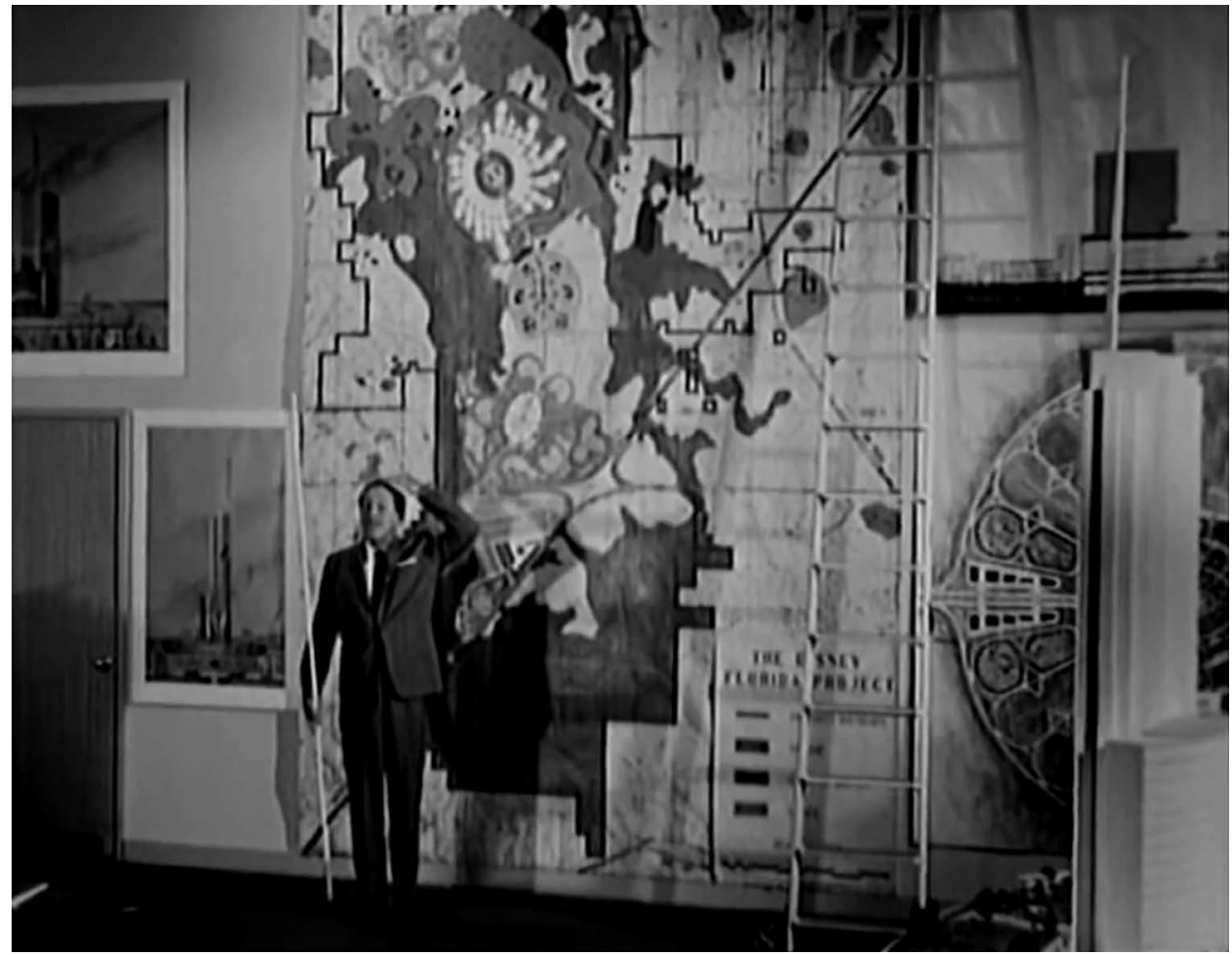

The EPCOT Film. https://youtu.be/UEm-09B0px8.

transportation systems. We then see Walt Disney in front of huge maps, talking about his vision. Again, transportation is foregrounded. The main means of transportation in EPCOT was to be a monorail and the so-called PeopleMover, a kind of paternoster on rails which would constantly move and which people could board and leave at any time. Cars would only be used for leaving and entering EPCOT, its main roads being underground.

There is certainly a strong utopian drive in the original concept for EPCOT (which was dropped almost immediately after Disney's death), but there is also a curious absence of politics. Disney is approaching 'the problems of our cities' with the mind-set of an engineer, or rather an 'imagineer'. Social and political tensions, insofar as they are even acknowledged, are reduced to technical problems. Classes, races, inequalities or the whole question of how this city is governed, are never mentioned.

Yet another completely different breed of utopian documentary are films that show that the present, as bad as it is, already contains utopian glimpses; little utopian enclaves on which we can build to create a better world. Two 
recent examples of this approach are Demain/Tomorrow (Dion and Laurent France 2015) and Where to Invade Next (Moore US 2015). Both films follow a similar pattern: they present examples of best practices, places and institutions that have implemented smart, forward-looking solutions to urgent problems. Moore, in his typical satirical attitude, mainly contrasts the US with Europe (and a few other countries), and focuses on labour, education and women's rights. Among others, he shows the long holidays in Italy, the works councils in Germany, the school system in Finland that achieves top results without homework or tests, and the strong standing of women in the government and finance industry of Iceland.

Tomorrow is less flamboyant than Moore's film and more interested in small initiatives and ecological concerns. We also see the Finnish school system, but, in addition, ecological farming, examples of urban gardening and the island of Réunion, which plans to cover all its needs with renewable energy by 2025 . There is a strong 'normative intention' in both films, especially in the case of Tomorrow. The film - which has been extremely successful in France (it sold over a million tickets at the box office) - is clearly intended to motivate its viewers to take the initiative and change the world, at least on a small scale.

These few examples, which I have only briefly touched upon, are meant to give an idea of the possible scope of non-fictional utopias. They range from public relation films, like the General Motors productions, to classic propaganda in the case of Land of Promise, to films that want to activate the audience, like Tomorrow. In the following section, I will take a closer look at Zeitgeist: Addendum (Joseph US 2008), a film that we can place more or less at the centre of these three poles, and that fits Schölderle's model even more closely.

\section{Zeitgeist}

Zeitgeist: Addendum is the second of three Zeitgeist movies, low-budget productions that are all freely available online.19 It was preceded by Zeitgeist: The Movie (Joseph US 2007) and followed by Zeitgeist: Moving Forward (Joseph US 2011). Joseph's films have created quite a stir on the web, one commentator even calling them 'the world's first Internet-based cult' (Goldberg).

Joseph's movies are a strange mixture of criticism of religion, esoteric thought and all kinds of conspiracy theories (including considerations of the

19. Available from www.zeitgeistmovie.com. 
terrorist attacks of 9/11).20 According to them, our world's great evils are caused by dark forces that are supported by the World Bank, the IMF and the US government, whose common goal is a totalitarian world state. Zeitgeist: The Movie dwells on these crude accusations, which are also 'covertly anti-Semitic' (Goldberg); Zeitgeist: Addendum, which focuses on economic questions, goes a step further and offers an alternative: the Venus Project.

The Venus Project - named after its location in Venus, Florida - is, in the words of its founders, 'an organization that proposes a feasible plan of action for social change, one that works towards a peaceful and sustainable global civilization' ('About The Venus Project'). The driving forces behind the project are industrial designer Jacque Fresco (born in 1916) and his partner Roxanne Meadows. For years, the two have been touting their ideas for a radical reorganisation of society. 21

In their diagnosis, Joseph and Fresco are in complete agreement: the basic evil of modern society is our money-based economy.22 Money is the root of all problems; it is the true source of crime, greed and corruption. As Joseph says in the movie's voice-over commentary: 'Virtually all forms of crime are a consequence of the monetary system'. Traditional political systems are unable to cope with the world's real problems, since they all rely on a money-based economy: 'All of the world's economic systems - socialism, communism, fascism and even the vaunted free enterprise system - perpetuate social stratification, elitism, nationalism and racism, primarily based on economic disparity' ('About The Venus Project'). The solution put forward by Fresco and Meadows, who get ample screen time in the movie, is their concept of a Resource Based

20. For Charlotte Ward and David Voas, the 'Zeitgeist Movement' is a typical example of what they call 'conspirituality', a 'hybrid of conspiracy theory and alternative spirituality [that] has appeared on the internet' (103). Traditionally, the realms of conspiracy theory and New Age beliefs seemed antithetical, but in the age of the Internet, unexpected synergies have popped up that somehow combine these opposing worldviews.

21. Already in 1969, Fresco, together with Kenneth Keyes, had published Looking Forward, a part fiction, part 'serious' futurology book that contains many of the concepts that would later become part of the Venus Project (see Seyferth). In Looking Forward, the solution to all problems lies in the "Correlation centre, "Corcen", a gigantic complex of computers that serves but never enslaves mankind. Corcen regulates production, communication, transportation and all other burdensome and monotonous tasks of the past' (4). In his newer books (The Best, Designing), Fresco adds an anticapitalist element. Now money is the source of all problems, and the solution is, again, the computer. For a thorough, yet slightly cumbersome, presentation of Fresco's thoughts, see Yates.

22 The relationship between Joseph and The Venus Project is complicated. The success of the Zeitgeist movies led to the founding of the Zeitgeist movement. Originally, the movement defined itself as activist arm of the Venus Project, but, as it so often happens with sect-like groups, the two organisations split in 2011 and are no longer associated with oneanother. 
Economy (RBE). It remains unclear exactly how an RBE is supposed to work, but its key feature is the 'intelligent management of the earth's resources', which is handled by computers. Thanks to the RBE and automation, no one has to go hungry, because 'with all our technology today, we can create abundance'.

At its core, the Venus Project is very suspicious of politics. Salvation can only come through science and technology. As Fresco says in the movie: 'it's technology that solves problems, not politics'. In the eyes of Fresco and Meadows, most problems have a single rational answer. Governance is not understood as the balancing of conflicting interests, but as arriving at the objectively correct solution. Therefore, the Venus Project is ultimately about getting rid of the political process altogether. Ultimately, no one has to decide anything anymore in an RBE. As the FAQ on their website puts it:

The process of arriving at decisions in this economy would not be based upon the opinions of politicians, corporate, or national interests but rather all decisions would be arrived at based upon the introduction of newer technologies and Earth's carrying capacity. Computers could provide this information with electronic sensors throughout the entire industrial, physical complex to arrive at more appropriate decisions.

Although Fresco refers to sf and utopian writers such as Edward Bellamy, H.G. Wells and B.F. Skinner, he rejects the term 'utopia' in connection with his work. In his understanding, utopias are always static, whereas the Venus Project evolves together with science. Fresco's opinion notwithstanding, it should be obvious that the world he envisions has much in common with classic utopian designs. Zeitgeist: Addendum offers a veritable catalogue of utopian topoi. After a harsh criticism of the status quo, its suggested alternative is characterised by rationality, collectivism, universalism and the abolition of money. Since everybody gets what they need - and only what they really need - most crimes disappear. As a consequence, laws become unnecessary. As Fresco says in the movie: 'All laws will disappear'. Ultimately, the state itself will therefore wither away: 'The state does nothing because there is no state'.

This statement is most remarkable. In a notable twist, a highly controlled society, where the distribution of goods is centrally organised, turns into a state without any governmental structure.23 While this is atypical for classic utopias, the Venus Project is very traditional in most other respects and fits Schölderle's model well. There are some obvious differences on a formal and structural level

23. As Michelle Goldberg notes, there is a veritable ideological shift between Joseph's first and second movie, 'from decrying a one-world system to embracing it'. Zeitgeist: The Movie adopts far-right fantasies about secret plans to build a world government, while Zeitgeist: Addendum advocates a global and centrally organised distribution of goods. However, as Fresco's statement about the withering away of the state indicates, the attitude towards the state is even more inconsistent. 
though: the movie lacks the typical narrative frame that, as discussed earlier, is common in classic utopias; but, considering the fact that I am deliberately looking at non-fiction films, this is hardly surprising. 24

Zeitgeist: Addendum follows traditional documentary conventions. Its voice-over commentary speaks with great authority; talking heads, charts, text inserts and different kinds of archive material - among them historical newsreel footage and old commercials - make up the bulk of the film's material, alongside contemporary TV programmes as well as purely symbolic images. Most of the footage is shown without any real context, even to the point that we simply do not know what we are looking at. For example, a statement on US foreign policy in the first third of the film is accompanied by images of jet fighters, tanks and a UN Security Council meeting. During the whole scene, no indication is given as to when and where this material was shot. This sequence, like many others, is rendered in black and white; through this manipulation, the footage not only matches better with the archival material, but it also enhances the impression of a historical documentary. 25

In the use of its material, Zeitgeist: Addendum proceeds like a typical news show, conveying all essential information either by voice-over commentary or through statements from individual protagonists. News shows often rely on completely interchangeable images of government buildings or politicians arriving in limousines and shaking hands, since the actual issue - for example, negotiations on a bilateral treaty - cannot be easily visualised. Zeitgeist: Addendum faces the same problem: its main concerns, especially the RBE that is at its core, are abstract and difficult to show. This is why much of its imagery has little direct connection with the content of the commentary, mainly serving as a kind of vague symbolic supplement. Almost completely missing are moments where an argument is developed non-verbally, through images. However, the opposite happens often; time and again, the screen turns black and we only hear Joseph's voice.

Visually, the most interesting moments are shots of Fresco's models and designs. We see cool-looking futuristic buildings, monorail and maglev trains,

24. In a somewhat ironic twist, the Venus Project is crowdfunding money for a feature film 'depicting life in a resource-based economy. This film would be designed to reach the general public throughout the world to introduce an exciting, sustainable new social direction' ('The Venus Project Motion Picture'). At an earlier date, the website stated that US\$198,000 had already been donated. Since then, this figure has disappeared. Now, and for over a year now, the following statement has been found online: 'We have completed the first draft of the script for this movie. We are exploring multiple avenues for funding, as we now have a producer who is on board with the film as well'.

25. There are also artificial scratches throughout the film. 

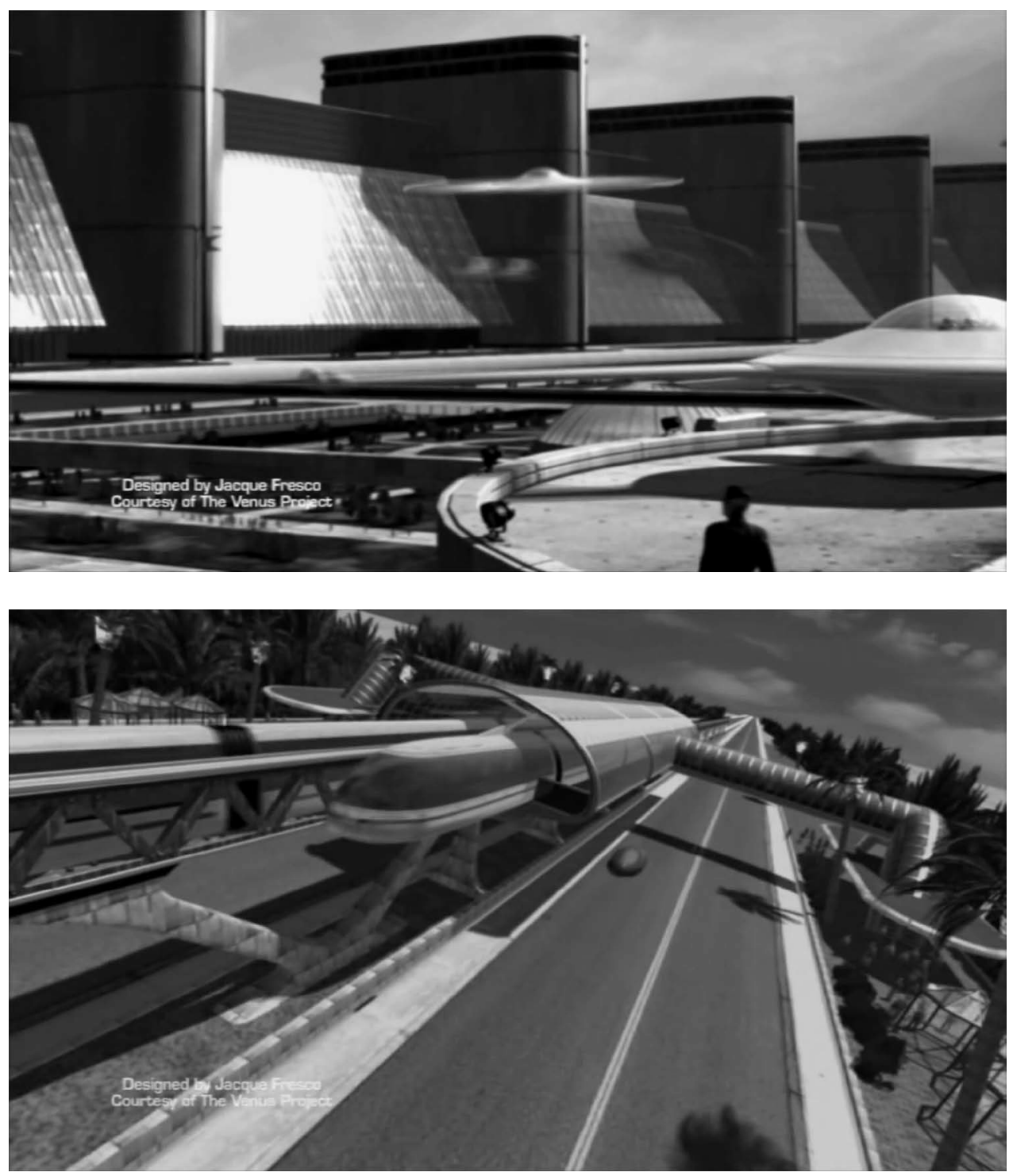

The future as envisioned by the Venus Project. Zeitgeist: Addendum. www.zeigeistmovie.com, 2008.

and other sf vehicles. There even are some computer animations that show the bright future the Venus Project will bring about. In its visual design, Fresco's vision is also firmly rooted in the utopian tradition. It is telling that many of his sketches - like Disney's designs for EPCOT - fall back on the concept of the circular city. There is a long history of symmetrical layouts for utopian cities. 


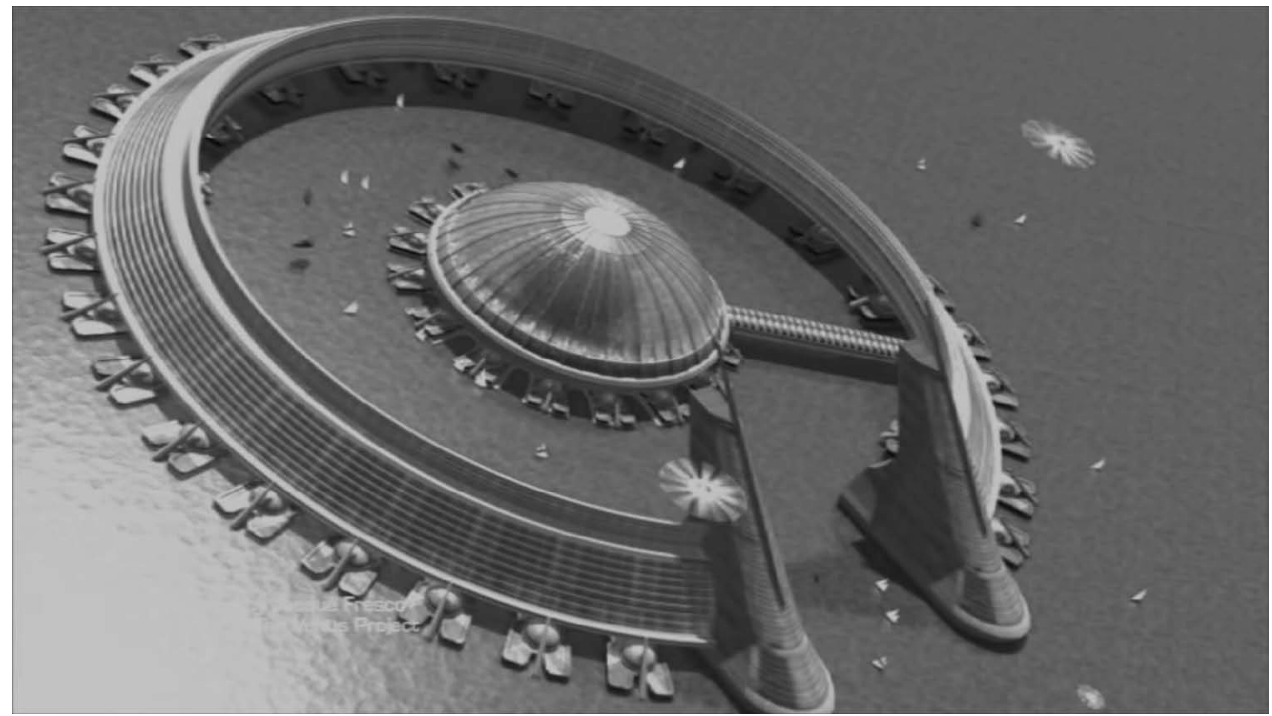

The Circular City. Zeitgeist: Addendum. www.zeigeistmovie.com, 2008.

Their geometric design is another indication of their rationality, but also of their model-like quality.

Compared to fiction films, Joseph's movie is definitely more explicit about how society should be run. Still, classic utopian texts such as Utopia, Tommaso Campanella's City of the Sun (1623), Edward Bellamy's Looking Backward (1888) or B.F. Skinner's Walden Two (1948) are much more detailed in their description. The reasons lie in the nature of the two media: while a written utopia describes its society, a movie like Zeitgeist: Addendum actually tries to show it.

The visual presentation is, of course, the big difference between written and filmic utopias: the utopian novel tries to convince its reader by explaining its organisation and institutions, and one of its main rhetorical strategies is completeness. The strength of a movie, on the other hand, lies not so much in detailed explanations and arguments, but in the persuasive power of the photographic image. Zeitgeist: Addendum is able to provide visual (and aural) impressions of its concepts: it can actually show what the world of the Venus Project would look like. 


\section{Documenting utopias}

If we accept the above examples as filmic utopias, several intriguing contradictions arise. Instead of talking about a historical reality inside a fictional frame, as the utopian novel does, they all use the trappings of the non-fiction film. This seems rather counterintuitive. Should documentaries (which are supposed to show the real world) be the best way to talk about utopian concepts, which, by their very definition, do not (yet) exist? To deal with these questions, a short digression into the theory of non-fiction film is in order.

'Every film is a documentary' (Nichols 1). Bill Nichols's provocative statement points directly at the fundamental problem when we try to define the non-fiction film: the photographic image always reproduces a pro-filmic event, independent of the question of whether this specific event was staged or not. By the same token, there have always been ways to manipulate film; and if we look at the history of film, the distinction between fiction and non-fiction some may take as a given has not always existed. To speak properly of a non-fiction film, a concept of a fictional film is first required. In the early days of film history, this had not yet been formed. Film historian Tom Gunning therefore does not speak of documentaries but of 'views' when he talks about early film.

It seems obvious, even trivial, that the salient feature of a documentary film is its higher degree of authenticity, its closer relation to reality; but it is actually quite difficult to pin this relation down on a theoretical level. Indeed, is there an indexical link between film and reality, or is this very reality instead presupposed and constructed by the film itself? Moreover, can we really distinguish between fiction and non-fiction film? Do not both - as Nichols's words imply - document what is happening in front of the camera? On an analytical level, these problems manifest themselves in the question of whether a film's status as non-fictional can be determined solely by its formal features, or whether it actually depends on the pragmatic context, for example, the information we receive in advance before we watch the film, the TV channel on which a film is shown and so on.

To reconcile these two positions, the semio-pragmatic approach put forward by French theorist Roger Odin proves useful.26 Odin's concept is based on the idea of a twofold production of film, which is performed by both the filmmaker and by the viewer. When we watch a movie, we do not simply passively perceive it, but actively produce it anew. This process is guided by different modes

26. To my knowledge, only two texts by Odin are available in English ('Semio-Pragmatics' and 'Reflections'). For an overview, see Buckland, 77-108. 
of reading, for example, 'fictionalising', 'documentary' and 'private'.27 The documentary mode, which is of interest here, is based on the 'construction of a real enunciator (as opposed to a fictive one)' ('Reflections' 255), a real entity that makes statements about the real world.

Carl Plantinga argues along similar lines when he sees 'the implicit directorial assertion of veridical representation' ('What' 111) as the defining moment of the documentary.28 According to this notion, a non-fiction film is always based on the implicit assumption that the film-maker 'asserts that the state of affairs making up that projected world holds or occurs in the actual world': he 'takes an assertive stance' ('What' 107). This does not mean that the individual image (or sound) used in a film cannot be staged or in any other way be manufactured, nor that what the film says must actually be true (or that there is even an identifiable film-maker). The crucial point is rather that the question of truthfulness only becomes meaningful in the documentary mode. Fiction makes no claims about the real world; asking whether a fiction film is truthful or not is meaningless. Fiction cannot lie. But, in the case of a documentary, this question starts to make sense. The statements made in a documentary are at least potentially verifiable. As Odin puts it: 'The question, not the answer, defines the documentary' ('Reflections' 256).

As viewers, we adopt different attitudes towards a film depending on the mode we choose. Once we adopt the documentary mode, '[b]oth enunciator and reader actant are modalized as real, with the result that the addressee must take seriously what is articulated on screen' (Buckland 96). Which mode we choose depends on a variety of parameters: internal markers in the film, conventions such as title and credit sequence, the context in which a film is shown, and our own previous knowledge. If I enter a cinema with the intention of watching a documentary, I will usually choose the appropriate mode. Furthermore, most films clearly indicate by way of established conventions how they should be watched; however, there are also situations where no clear indication is given. For example, when I watch television, I may accidentally jump into the middle of movie without immediately knowing its intended mode. I may also deliberately refuse to adopt the mode suggested by the movie and instead choose my own - for example, I can watch a movie as a document of its era's typical acting style.

27. The French documentarisant is sometimes translated as 'documentarist' and sometimes as 'documentary'. Odin does not intend to give a definite list of modes. In fact, over the years, he himself has expanded the number of possible modes.

28. The main difference is the concept of the enunciator, of which Plantinga is highly critical (116, fn. 15). 
As I have already explained, it makes no sense to ask whether a fiction film is true or not. But it can - and probably always does - contain elements of the real world. There is a long theoretical debate on this subject, especially on the case of historical characters appearing in fictional accounts. This case is often referred to as the 'Napoleon problem': is the character of Napoleon Bonaparte appearing in fiction - for example, in Leo Tolstoy's War and Peace (1869) - the real Napoleon? Different opinions do exist on this subject, but the general consensus is that, once it becomes part of fiction, a historical character like Napoleon ceases to be real and is fictionalised.

On the other hand, the opposite case - the use of fictitious elements in a documentary - has been given very little attention. This is surprising, because, on closer inspection, documentaries that, in a seemingly paradoxical fashion, include fictitious elements are not at all uncommon. Propaganda movies,29 for example, often deal with scenarios that are not (yet) real: the enemy's destruction, the victory of a political party, the results of a great reform and so on. This is, of course, exactly what happens - with the exception of Tomorrow and Where to Invade Next - in the films I have discussed. They all show us versions of a better future. In To New Horizons, and especially in The EPCOT Film and Zeitgeist: Addendum, we see images of cities that are not reproductions of the real world, but of its avowed alternative or continuation.

In fiction films, elements of the actual world are fictionalised; in documentaries, the opposite occurs. While the buildings and vehicles shown in Walt Disney's and Peter Joseph's films are not (yet) real, they also cease to be completely fictional. The point these films try to make is precisely that the things we see are both plausible and desirable. The fictitious elements therefore lose their non-real status to some degree and become quasi-assertive. I shall call this process of making things appear quasi-real factualisation.30

There are interesting overlaps between these utopian documentaries and TV shows such as Walking with Dinosaurs (UK 1999) or Dragons: A Fantasy Made Real (UK 2004), which Anneke Metz has discussed in an enlightening article. These shows present animals - dinosaurs and dragons, respectively - which

29. There is wide consensus that propaganda and documentary films partly overlap. How much they do so depends mainly on how narrowly we define propaganda. If we understand propaganda very broadly as any kind of 'planned attempt ... to manipulate by means of communication the opinions, attitudes, and the behaviour of a target group in order to achieve a political goal' (Maletzke 157), the corpus will be wider compared to if we think of propaganda solely as a means to fight an external enemy (Ellsworth; Neale 'Propaganda'). Plantinga argues that every nonfictional movie at least implicitly takes a position towards the things it shows ('Rhetoric' 99), which already indicates a discursive and rhetorical closeness to propaganda.

30. I am indebted to my colleague, Andrea Reiter, for coming up with this term. 
do not (now) exist. Metz, using a term from James M. Moran and Mark J.P. Wolf, calls them 'subjunctive documentaries'. Although the things depicted have a different ontological status - dinosaurs did exist, dragons did not and whether Disney's or Fresco's visions would become a reality was, at the time of production, at least doubtful - there are obvious similarities. In all instances, non-real things, which are normally the material of sf and fantasy, become the subject of a documentary.

According to Metz, these shows systematically disguise the fictitious status of their content. CGI plays a key role here, since it, supposedly, makes use of scientific models to create photorealistic imagery. What is left unsaid is that these models are, at best, approximations that have been created for maximum visual effect. As Metz states: 'These subjunctive documentaries are profoundly aggressive in their insistence that the fictions they are "documenting" not only could be real but truly are real, because CGI has made them so' (343).

Statements given by respected scientists are another important device. According to Metz, these statements do not even have to support what is shown: the mere presence of a scientist is enough to create the impression of scientific respectability. Whether a particular scientist is actually talking about her area of expertise is basically irrelevant.

Both devices are also employed by the utopian movies I have foregrounded in this essay, especially in The EPCOT Film and Zeitgeist: Addendum. The fact that the sketches, paintings and animations they use are not photorealistic is not to their disadvantage: it rather underscores that these are designs created by professionals - which they actually are - and not just some arbitrary drawings. While The EPCOT Film draws mainly on Walt Disney's enormous popularity, Joseph lacks well-known interview partners. Still, he employs similar techniques. The film randomly inserts quotations from more or less famous people to give its content a certain gravitas; but above all, Fresco himself is framed as a technical expert: when he talks, he sits in his workshop, a drawing table with a futuristic drawing on his right and more sketches on the wall behind his back. The message is quite clear: this is a competent craftsman who knows his business.

According to Metz, shows like Walking with Dinosaurs 'present science fiction as scientific truth' (343), an approach she deems highly problematic. Similar things could be said about the utopian films discussed here. With the exception of Tomorrow and Where to Invade Next, and to some degree also Promised Land, they all present typical sf nova as things that can soon be realised, as (scientific) facts. Like sf, they let their nova appear as plausible and logical extensions of the existing world. The big difference, of course, is 


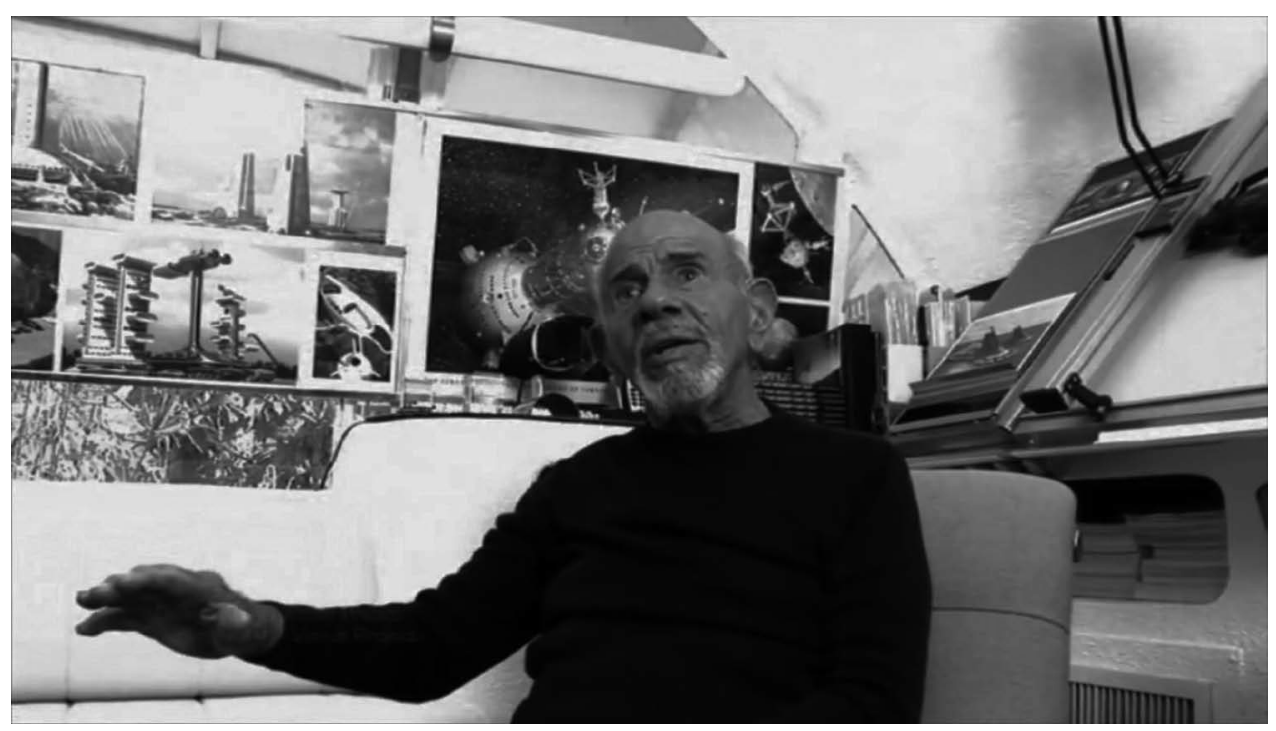

Jacque Fresco in his studio. Zeitgeist: Addendum. www.zeigeistmovie.com, 2008.

one of reference. In the case of sf, the context is fictional, while documentaries supposedly reflect the real world. This changes the status of the novum completely; it becomes factualised and quasi-assertive.

In a factualised or subjunctive documentary, the question of how non-fiction film and reality relate becomes even more pressing. Here, the enunciator (or filmmaker) who normally serves as warrantor loses his credibility. When it comes to fictitious elements, his statements potentially cannot be verified, at least not in the present. In the case of the filmic utopia, this becomes highly problematic, since the world shown is, by definition, not (yet) real. A movie like Zeitgeist: Addendum therefore runs the risk that a viewer will stop perceiving it in a documentary mode, treating it instead as sf. This is why the film goes to great lengths to present the ideas put forward by the Venus Project as serious propositions.

From this point of view, written and filmed utopias are not that far apart. To work properly as a critical alternative, the written utopia also needs to be perceived as reasonably plausible. The two crucial means to achieve this are the typically detailed descriptions and the long discussions between the utopian guide and the outsider: these both serve to 'prove' why the particular utopian order is the only sensible one. In this context, it does not matter whether a utopia is meant to be realised or not. In either case, the proposed society must at least appear to be worthy of consideration; if it just feels like a silly joke, it is 
unable to function as a critical counterimage. In this respect, the strategy used by written utopias does resemble the operation of factualisation. For example, in the first book of Utopia, More criticises the English justice system in a very detailed fashion. This criticism is assertive by nature, since it makes the propositions of the second book appear more relevant. What Hythloday tells us about the island of Utopia may not be verifiable, but the first part has assured us of the book's relevance and importance. Certainly, the assertive stance of the written utopia is normally not as pronounced as in a documentary. Still, the written utopia's closer connection to reality shows many similarities to the device of factualisation.

What I have been describing in this article is the theoretical base of my current research project, funded by the Swiss National Science Foundation.31 Although I have only been able to offer a brief sketch, I hope I have still been able to show that the medium of film offers vast uncharted territories for utopian studies. Previous research looking at fiction films has been misguided, since written utopias are simply not fiction proper; it is therefore no surprise that no one could come up with a feature film that even remotely resembles a classic utopia. However, once we turn away from fiction, there are many possibilities for utopian films.

\section{Works cited}

Altman, Rick. Film/Genre. London: BFI, 2000.

Balasopoulos, Antonis. 'Anti-Utopia and Dystopia: Rethinking the Generic Field'. Utopia Project Archive, 2006-2010. Ed. Vassilis Vlastaras. Athens: School of Fine Arts, 2011. Bellamy, Edward. Looking Backward: 2000-1887. Ed. Matthew Beaumont. New York: Oxford UP, 2009.

Blaim, Artur. Gazing in Useless Wonder: English Utopian Fictions, 1516-1800. Oxford: Peter Lang, 2013.

Buckland, Warren. The Cognitive Semiotics of Film. Cambridge: Cambridge UP, 2000.

Campanella, Tommaso. The City of the Sun: A Poetical Dialogue. Berkeley: U of California P, 1981.

Ellsworth, Elizabeth. 'I Pledge Allegiance: The Politics of Reading and Using Educational Films'. Curriculum Inquiry 21.1 (1991): 41-64.

Endter, Heike. Ökonomische Utopien und ihre visuelle Umsetzung in Science-FictionFilmen. Nürnberg: Verlag für moderne Kunst Nürnberg, 2011.

Fitting, Peter. 'What Is Utopian Film: An Introductory Taxonomy'. Utopian Studies 4.2 (1993): 1-17.

31. I regularly report on my project on my blog: www.utopia2016.ch. 
Fresco, Jacque. The Best that Money Can't Buy: Beyond Politics, Poverty and War. Venus: Global Cyber-Visions, 2002.

-. Designing the Future. Venus: The Venus Project, 2007.

Gennawey, Sam. Walt and the Promise of Progress City. Pike Road: Ayefour, 2011.

Goldberg, Michelle. 'Brave New World'. Tablet. 2 Feb 2011. http://tabletmag.com/jewishnews-and-politics/57732/brave-new-world. Accessed 11 Jun 2015.

Greenblatt, Stephen. Renaissance Self-fashioning: From More to Shakespeare. Chicago: U of Chicago P, 2005.

Gunning, Tom. 'Before Documentary: Early Nonfiction Films and the "View" Aesthetic'. Uncharted Territory. Essays on Early Nonfiction Film. Ed. Daan Hertogs and Nico de Klerk. Amsterdam: Netherlands Film Museum, 1997. 9-24.

Keyes, Kenneth, and Jacque Fresco. Looking Forward. South Brunswick: A.S. Barnes, 1969.

Knight, Cher Krause. Power and Paradise in Walt Disney's World. Gainesville: UP of Florida, 2014.

Koselleck, Reinhart. 'Die Verzeitlichung der Utopie'. Utopieforschung. Interdisziplinäre Studien zur neuzeitlichen Utopie. Vol. 3. Ed. Wilhelm Voßkamp. Frankfurt am Main: Suhrkamp, 1985.

Kuon, Peter. Utopischer Entwurf und fiktionale Vermittlung: Studien zum Gattungswandel der literarischen Utopie zwischen Humanismus und Frühaufklärung. Heidelberg: Universitätsverlag Winter, 1986.

Layh, Susanna. Finstere neue Welten: Gattungsparadigmatische Transformationen der literarischen Utopie und Dystopie. Würzburg: Königshausen \& Neumann, 2014.

Levitas, Ruth. Utopia as Method. The Imaginary Reconstitution of Society. Basingstoke: Palgrave Macmillan, 2013.

Maletzke, Gerhard. 'Propaganda: Eine begriffskritische Analyse'. Publizistik 17.2 (1972): 153-64.

McCutcheon, Elizabeth. 'Denying the Contrary: More's Use of Litotes in the Utopia'. Moreana 31.2 (1971): 107-22.

Metz, Anneke M. 'A Fantasy Made Real: The Evolution of the Subjunctive Documentary on U.S. Cable Science Channels'. Television \& New Media 9.4 (2008): 333-48.

Moran, James M. 'A Bone of Contention: Documenting the Prehistoric Subject'. Collecting Visible Evidence. Ed. Jane M. Gaines and Michael Renov. Minneapolis: U of Minnesota P, 1999.

More, Thomas. Utopia. Ed. Edward Surz and J. H. Hexter. The Yale Edition of the Complete Works of St. Thomas More. Vol. 4. New Haven: Yale UP, 1979.

Morris, William. 'News from Nowhere'. News from Nowhere and Other Writings. Ed. Clive Wilmer. London: Penguin, 1998.

Moylan, Tom. Demand the Impossible: Science Fiction and the Utopian Imagination. Ed. Raffaella Baccolini. Oxford: Peter Lang, 2014.

Müller, André. Film und Utopie: Positionen des fiktionalen Films zwischen Gattungstraditionen und gesellschaftlichen Zukunftsdiskursen. Berlin: Lit, 2010.

Neale, Steve. 'Propaganda'. Screen 18.3 (1977): 9-40.

-. Genre and Hollywood. London/New York: Routledge, 2000.

Nichols, Bill. Introduction to Documentary. Bloomington: Indiana UP, 2001 
Odin, Roger. 'For a Semio-Pragmatics of Film'. The Film Spectator. From Sign to Mind. Ed. Warren Buckland. Amsterdam: Amsterdam UP, 1995.

- ' 'Reflections on the Family Home Movie as Document: A Semio-Pragmatic Approach'. Mining the Home Movie: Excavations in Histories and Memories. Ed. Karen I. Ishizuka and Patricia R. Zimmermann. Berkeley: U of California P, 2008.

Plantinga, Carl R. Rhetoric and Representation in Nonfiction Film. Cambridge: Cambridge UP, 1997.

-. 'What a Documentary is, After all'. The Journal of Aesthetics and Art Criticism 63.2 (2005): 105-17.

Pohl, Nicole. 'Utopianism after More: The Renaissance and Enlightenment'. The Cambridge Companion to Utopian Literature. Ed. Gregory Claeys. Cambridge: Cambridge UP, 2010.

Ricoeur, Paul. Lectures on Ideology and Utopia. Ed. George Taylor. New York: Columbia UP, 1986.

Roberts, Adam. The History of Science Fiction. Basingstoke: Palgrave Macmillan, 2006.

Saage, Richard. 'Plädoyer für den klassischen Utopiebegriff. Erwägen, Wissen, Ethik 16.3 (2005): 291-8.

-. 'Zum analytischen Potenzial des klassischen Utopiebegriffs'. Idealstaat oder Gedankenexperiment? Zum Staatsverständnis in den klassischen Utopien. Ed. Thomas Schölderle. Baden-Baden: Nomos, 2014.

Sargent, Lyman Tower. 'The Three Faces of Utopianism Revisited'. Utopian Studies 5.1 (1994): 1-37.

—. 'In Defense of Utopia'. Diogenes 53.1 (2006): 11-17.

Schölderle, Thomas. Utopia und Utopie: Thomas Morus, die Geschichte der Utopie und die Kontroverse um ihren Begriff. Baden-Baden: Nomos, 2011.

Seeber, Hans Ulrich. Wandlungen der Form in der literarischen Utopie. Studien zur Entfaltung des utopischen Romans in England. Göppingen: Kümmerle, 1970.

Seyferth, Peter. 'Die Abschaffung der Politik als politische Utopie. Politikwissenschaftliche und fantastische Perspektiven auf das Venus Project'. Übergänge und Entgrenzungen in der Fantastik. Ed. Christine Lötscher, Petra Schrackmann, Ingrid Tomkowiak and Aleta-Amirée von Holzen. Berlin: Lit, 2014.

Skinner, B. F. Walden Two. Englewood Cliffs: Prentice-Hall, 1976.

Skinner, Quentin. 'Sir Thomas More's Utopia and the Language of Renaissance Humanism'. The Languages of Political Theory in Early-Modern Europe. Ed. Anthony Pagden. Cambridge: Cambridge UP, 1987.

Spiegel, Simon. 'Things Made Strange. On the Concept of "Estrangement" in Science Fiction Theory'. Science Fiction Studies 35.3 (2008): 369-85.

- . 'Bilder einer besseren Welt: Über das ambivalente Verhältnis von Utopie und Dystopie'. Das Science Fiction Jahr 2008. Ed. Sascha Mamczak and Wolfgang Jeschke. München: Heyne, 2008.

—. 'Authentische Wunschträume: Einige Überlegungen zur Utopie im nichtfiktionalen Film'. Komparatistik Online 1 (2013): 188-99.

-. 'Auf der Suche nach dem utopischen Film'. Übergänge und Entgrenzungen in der Fantastik. Ed. Christine Lötscher, Petra Schrackmann, Ingrid Tomkowiak and Aleta-Amirée von Holzen. Berlin: Lit, 2014. 
-. Rev. of Unterwegs zu neuen Welten, by Sebastian Stoppe. Journal of the Fantastic in the Arts 26.3 (2015): 617-20.

Stoppe, Sebastian. Unterwegs zu neuen Welten. Star Trek als politische Utopie. Darmstadt: Büchner, 2014.

Tietgen, Jörn. 'Political Utopias in Film'. Spaces of Utopia: An Electronic Journal 3 (2006): 114-31.

The Venus Project. 'About The Venus Project'. https://www.thevenusproject.com/en/ about/the-venus-project. Accessed 11 Jun 2015.

—. 'Frequently Asked Questions'. https://www.thevenusproject.com/en/faq. Accessed 11 Jun 2015.

-. 'The Venus Project Motion Picture'. https://www.thevenusproject.com/en/donate/ major-motion-picture. Accessed 11 Jun 2015.

Tryster, Hillel. 'The Land of Promise (1935): A Case Study in Zionist Film Propaganda'. Historical Journal of Film, Radio and Television 15.2 (1995): 187-217.

Voßkamp, Wilhelm. 'Möglichkeitsdenken. Utopie und Dystopie in der Gegenwart: Einleitung'. Möglichkeitsdenken. Utopie und Dystopie in der Gegenwart. Ed. Wilhelm Voßkamp, Günter Blamberger and Martin Roussel. Paderborn: Fink, 2013.

Ward, Charlotte and David Voas. 'The Emergence of Conspirituality'. Journal of Contemporary Religion 26.1 (2011): 103-21.

Werder, Peter R. Utopien der Gegenwart. Zwischen Tradition, Fokussierung und Virtualität. Zürich: Seismo, 2009.

Winstanley, Gerrard. 'The Law of Freedom in a Platform: Or, True Magistracy Restored'. The Complete Works of Gerrard Winstanley. Ed. Thomas N. Corns, Ann Hughes and David Loewenstein. Oxford: Oxford UP, 2009.

Wolf, Mark J.P. 'Subjunctive Documentary. Computer Imaging and Simulation'. Collecting Visible Evidence. Ed. Jane M. Gaines and Michael Renov. Minneapolis: U of Minnesota P, 1999.

Yates, Shaun. 'Crime, Criminality \& Social Revolution'. MA thesis. U of Central Lancashire, 2014.

Zeissler, Elena. Dunkle Welten: Die Dystopie auf dem Weg ins 21. Jahrhundert. Marburg: Tectum-Verlag, 2008.

Zirnstein, Chloé. Zwischen Fakt und Fiktion: Die politische Utopie im Film. München: Utz, 2006. 